\author{
L'ubica Kubicová \\ PhD., Associate Professor of Department of Marketing and Trade, Faculty of Economics and Management, \\ Slovak University of Agriculture (Nitra, Slovakia); \\ Zdenka Kádeková, \\ PhD., Department of Marketing and Trade, Faculty of Economics and Management, \\ Slovak University of Agriculture (Nitra, Slovakia); \\ L'udmila Nagyová, \\ PhD., Professor of Department of Marketing and Trade, Faculty of Economics and Management, \\ Slovak University of Agriculture (Nitra, Slovakia) \\ Patrik Rovný, \\ PhD., Associate Professor of Department of Marketing and Trade, Faculty of Economics and Management, \\ Slovak University of Agriculture (Nitra, Slovakia)
}

\title{
SLOVAK CUSTUMERS DEMAND FOR DAIRY PRODUCTS AND MILK: ANALYSIS OF PRICE AND INCOME RELATIONS
}

The aim of the paper was the quantitative analysis of the determinants of demand and the level of consumption of milk and dairy products in relation to consumer prices of dairy products and disposable income in terms of consumer segment of households with dependent children.Current economic conditions in Slovakia contribute to the differentiation of the behavior of individual households on consumer market. It is noticeable mainly in families with several dependent children, where in 2012 the real money income of households with three or more dependent children was amounted to only $54.65 \%$ of the real income compared with incomes of families without dependent children and $66.21 \%$ of the income of families with one dependent child. In Slovak households the consumption of milk decreases in general and since 1998 has decreased overall by 13.3 liters and in 2012 reached the level 50.61 liters per person in families without dependent children and 45.58 liters in families with three or more dependent children. The demand for milk did not develop according to theoretical assumptions. Increase in price did not cause decrease in demand excluding the families with one dependent child. Based on indirect (cross) price elasticity can be expressed that demand was elastic and was substituted in the families without children $\left(E q_{i}, P_{2}=1.062\right)$ and in the households with three or more dependent children $\left(E q_{i}, P_{2}=2.373\right)$ by other milk products. Consumer demand for cheese and yoghurt fulfilled complementary (additional) function of nutrition ( $E q_{i}, P_{3}=-2.468$ to -0.249 ). Noticeable complementarity showed demand for yogurt in families with three or more dependent children $\left(E q_{i}, p_{4}=\right.$. 3.644), and families without dependent children ( $\left.E q_{i}, p_{4}=-2.27\right)$.

Keywords: income, consumption, price and income elasticity, substitution, complementarity.

DOI: 10.21272/mmi.2017.3-16

Introduction. Milk and dairy products take an important place in human nutrition. The high biological value of milk and dairy products for human consumption is given by a number of important nutrients, as well as their utilization. The basic components of milk besides the water are also the proteins of which the most important is casein, as well as fats and milk sugar lactose [13]. An important characteristic of fats and oils is that in their liquid form are soluble vitamins A, D, E, K. Of these vitamis it is vitamin A that achieves the highest concentration in milk fat, therefore in nutrition can be the milk fat considered as the main source of vitamin A [26]. In addition to essential nutrients and corresponding energy the milk provides a lot of substances that are characterized by nutritional, functional as well as by health effects [28, p. 15].

The nutritional value of milk is due to the presence of lactose, proteins, lipids and inorganic elements. Bioactive compounds in milk perform many functions other than nutritional, e.g., immune system, hormones and related compounds, antibacterial agents, enzymes, enzyme inhibitors and cryptic peptides. Biologically active milk compounds in the form of immunoglobulins, antibacterial peptides, 
Л. Кубіцова, 3. Кадекова, Л. Нагіова, П. Ровний. Попит словацьких споживачів на молочні продукти та молоко: аналіз залежностей цін та доходів

antimicrobial proteins, oligosaccharides and lipids protect neonates and adults against pathogens and illnesses [7, p. 437].

Another important and the most hyped advantage of milk and dairy products is calcium $(120 \mathrm{~g}$ in $1000 \mathrm{~g}$ of whole milk) in soluble forms important for bone growth, respectively - to prevent thinning bones - osteoporosis. Austrian Society for Nutrition (OGE-Österreichische Gesellschaft für Ernährung) and the German Society for Nutrition (DGE) recommend adults consumption of two to three servings of dairy products a day, for example in the form of half a pint of milk and 50-60 grams of cheese, noting that at present is this level of consumption below in all age groups of the population as can be seen in Table1 [10, p.430].

Table 1 - The Share of Milk and Dairy Products in the Total Intake of Calcium (Ca) in mg per day [10]

\begin{tabular}{|l|c|c|c|c|}
\hline \multicolumn{1}{|c|}{ Age Group } & Total Intake of Ca & Ca from milk & Ca from cheese & $\begin{array}{c}\text { Ca from } \\
\text { milk and cheese in \% }\end{array}$ \\
\hline $7-10$ years & 686 & 289 & 123 & 60 \\
\hline $13-15$ years & 651 & 249 & 129 & 58 \\
\hline $10-13$ years & 654 & 254 & 132 & 59 \\
\hline 18-65 years & 776 & 171 & 236 & 53 \\
\hline over 65 years & 682 & 214 & 155 & 54 \\
\hline
\end{tabular}

To children and youth is recommended increased intake of calcium in milk, which would correspond to the equivalent of $15 \mathrm{~g}$ of hard and $30 \mathrm{~g}$ of soft cheese per $100 \mathrm{ml}$ of milk. These calculations showed the following daily consumption of milk and milk products [25, p.487]. Besides price and demand factors there are also other, non-economic factors, that affect consumption of food, milk including, food choice and purchasing processes [14, p.407]. Detailed mapping of consumer behavior and responses gains importance in recent years as a result of global economic problems and financial recession, when consumers reassess the volume and financial costs of their purchases more than ever [20, p.1040]. Various advanced techniques as neuroimaging and biometric techniques are used to survey the unconscious components of consumer perception. They help to uncover hidden customer reactions and identify relations between internal emotions and external consumer manifestation and real buying behavior [1, p. 25].

In the group of 18-65 years old consumers it plays the most important role the cheese consumption, while for children the main sources of calcium are milk and dairy products, whose share increases in older age groups especially over 65 years.

Milk is also essential in the diet of vegetarians for its content of vitamin B12, which is basically found only in animal products, and is valuable and suitable combination of diet with certain plant proteins such as potatoes and cereals [5, p. 512]. Production of milk and its processing into dairy products is a permanent part of the integrated interplay chain of agriculture and food industry. Consumption of fresh dairy products is the other driver of dairy products in the EU. In the development the decreasing consumption of milk is substituted by increasing consumption of fermented milk products [8, p. 21].

Methodology. The aim of the paper was the quantitative analysis of the determinants of demand and the level of consumption of milk and dairy products in relation to consumer prices of dairy products and disposable income in terms of consumer segment of households with dependent children.

For the empirical estimation of demand functions of selected dairy products in relation to net cash inflows and the prices of dairy products was used a linear regression model. Research of price and income bonds in consumer demand for milk and dairy products was based on the database SRCOICOP. From the household budget survey data was collected data about the purchase of milk and dairy products and the nominal amount of net cash income of private households per person per year 
with regard to the number of dependent children.

The choice of linear representations of cost-income depending is from the basic level of these relations when examined consumer demand is relatively insufficient. In addition, this formulation provides easily interpreted results, which for more dynamic model is also very important [21,p.170].

Linear regression model of demand for dairy products (Qi) is based on following relations:

$$
Q_{i}=f\left(P_{1}, l,\right)+e_{i},
$$

respectively multiple regression:

$$
Q_{i}=f\left(P_{1}, P_{2}, . ., P_{n}, I\right)+e_{i}
$$

where: $Q_{i}-$ demand for ith dairy product in kg per person per year; $P_{1}, P_{2}, . ., P_{n}-$ prices of individual $i^{\text {th }}$ dairy products in $€ . \mathrm{kg}^{-1} ; \mathrm{I}$ - net cash income in $€$ per person per year; $\mathrm{e}_{\mathrm{i}}=$ random, residual component.

Price elasticity of demand for food Qi based on linear demand function is calculated according to the formula:

$$
\mathrm{E}_{\mathrm{PDi}}=\mathrm{b}_{\mathrm{i}} \frac{\overline{P_{i}}}{\bar{q}_{i}} .
$$

Income elasticity of demand for food Qi based on linear demand function is calculated according to the formula:

$$
\mathrm{E}_{\mathrm{IDi}}=\mathrm{b}_{1} \frac{\bar{I}}{\overline{q_{i}}}
$$

Indirect (cross) price elasticity of demand shows the relationship:

$$
E_{P D j}=b_{j} \frac{\overline{P_{j}}}{\overline{q_{i}}} .
$$

Changes in development of monitored indicators for the whole period of the time series we are described by the average growth rate $\mathrm{k}^{\prime}$

where:

$$
\mathrm{k}^{\prime}=\sqrt[T-1]{k_{1}} * k_{2} \ldots . . k_{i} \ldots k_{T},
$$

$$
k_{i}=y_{t} y_{t-1} \text { in years } i=2,3, \ldots, T \text {. }
$$

Results and Discussion. Development of Milk and Dairy Products Consumption in the Slovak Republic. Milk and dairy products are irreplaceable in daily food consumption mainly because the milk is a complete food by itself and in addition to vitamin $\mathrm{C}$ and iron contains other essential ingredients for healthy human development. Under Council Regulation (EC) No. 1234/2007, the dairy product means product derived exclusively from milk, while may be added further substances necessary for its production insofar these substances are not used to completely or partly replaced the milk constituents. 
Amino acids in milk are present as a complex compound containing calcium, phosphorus and less amount of magnesium. The remaining part of the protein consists of whey protein. The largest part up to $82 \%$ takes the protein casein which is also the exclusive milk protein and does not exist anywhere else in nature [4, p. 194].

Low-fat milk consumption might have favorable short-term effects on satiety and energy intake in obese children. Milk consumption behavior of adults between the ages of 25-49 were investigated using a telephone survey. It was found that the bulk of milk was drunk by a relatively small portion of the respondents and consumption decreased with increasing age. Plain milk was consumed at home principally in the evening and almost always cold [18; 11]. At young age physical activity and dairy consumption positively influence bone mass. Promoting physical activity and dairy consumption in young children may, therefore, maximize peak bone mass, an important protective factor against osteoporosis later in life [3, p. 1480].

Studies have shown that whey and casein are the major proteins found in milk which increase insulin, cholecystokinin (CCK), and glucagon-like peptide-1 (GLP-1) levels, which in turn lead to the suppression of appetite and energy intake [2; 6]. The other component of milk products which may affect the energy intake and satiety is lactose, which is classified as a low glycemic index (LGI) carbohydrate [9, p. 439]. Trend of milk consumption per person in Slovakia during the years (2004-2013) had a downward trend, with the exception of cheese, cottage cheese and sour milk products, which illustrates Figure1.

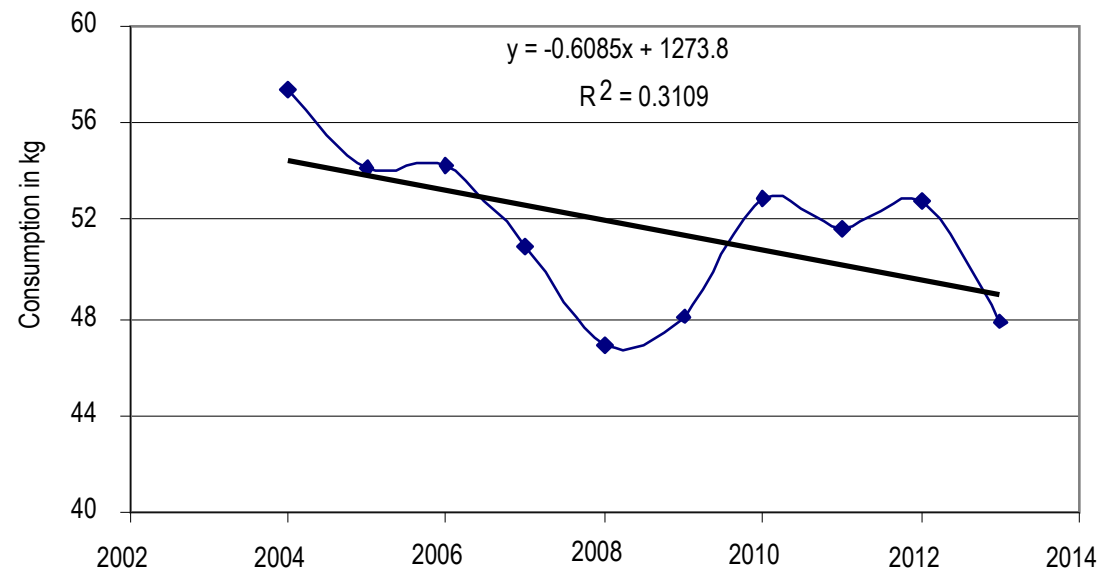

Figure 1 - Development of Milk Consumption (authors' research)

The downward trend in consumption of milk (Figure 1) has been observed since 2000, when consumption fell to $70 \mathrm{~kg}$ per person per year, followed by 2004, with a decrease in the average annual consumption of less than $50 \mathrm{~kg}$. On this, in terms of health professional misconduct by consumers and declining share of consumption of milk in the last decade, growing progeny was mainly accompanied by intensifying advertising ratios of available products made from milk and flavored beverages. In terms of nutrition as a positive development trend is seen an increasing growth in supply and demand for yoghurt, cheese and sour milk products $[13 ; 15 ; 16]$.

Development of milk and dairy products consumption (Figure 2) is marked by two different developmental stages. By 2009 , consumption had slightly fluctuated, hovering at the level of $152.4 \mathrm{~kg}$ to $154 \mathrm{~kg}$ per person. Increase of milk and dairy products consumption has been evident since 2010 . Overall, based on average growth rate $k^{\prime}$ can be concluded that there has been a growth in the 
consumption of milk and dairy products by an average annual rate of $0.4 \%$. Since the recommended consumption of milk and dairy products is $220 \mathrm{~kg}$ and rational consumption zone is 206 to $240 \mathrm{~kg}$ per person, the current development of milk consumption of can be evaluated as unfavorable.

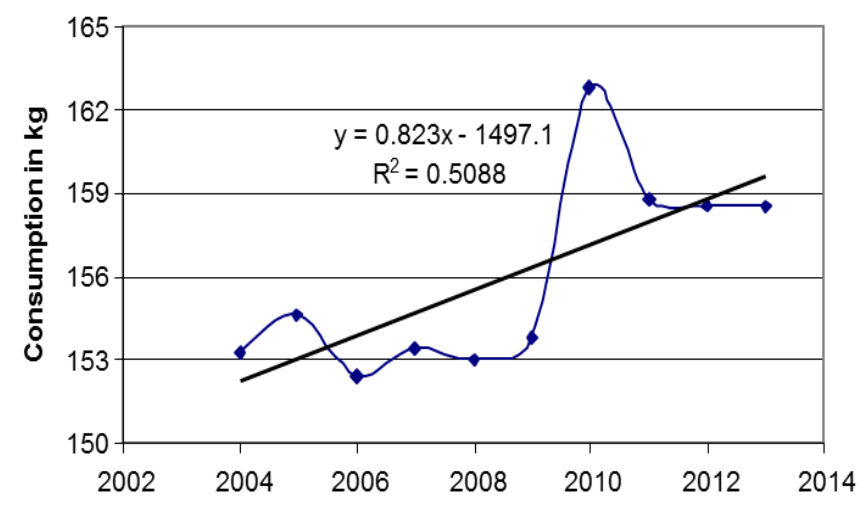

Figure 2 - Development of Milk and Dairy Products Consumption (authors' research)

In recent years has been noticed a concave course of an increase in consumption of other dairy products with higher added value, mainly cheese and curd (Figure 3).

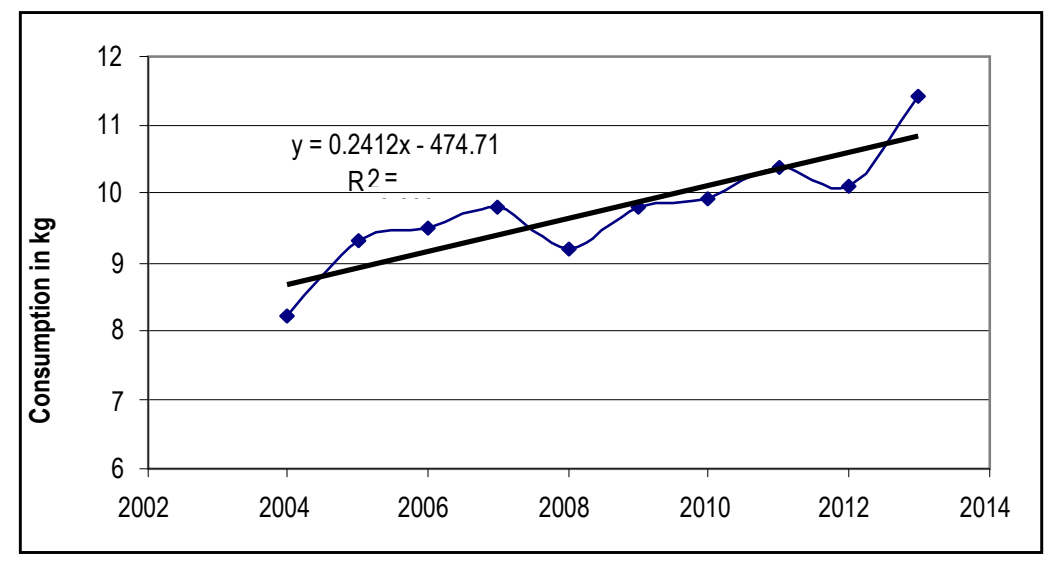

Figure 3 - Development of Cheese and Curd Consumption (authors' research)

On the basis of the average growth rate $k^{\prime}$ can be concluded that there was an increase in consumption of cheese and curd by an average annual rate of $2.1 \%\left(k^{\prime}=1.021\right)$, while consumption of milk decreased on average by $2.0 \%$ per year $\left(k^{\prime}=0.98\right)$. Slovak consumer, despite an increase in cheese consumption in 2013 to $11.2 \mathrm{~kg}$ per person, lags far behind the mentioned consumption in developed countries, especially in Germany $(21.8 \mathrm{~kg})$, France $(24.4 \mathrm{~kg})$ and Czech Republic $(16.8 \mathrm{~kg})$.

Development of Real Net Cash Income and Real Expenditures on Food and Non-alcoholic Beverages in Households with Dependent Children in $€$ per Person per Year in Slovakia. In the period 2004-2012 the real net cash income of the population increased in families without dependent children by a 
Л. Кубіцова, 3. Кадекова, Л. Нагіова, П. Ровний. Попит словацьких споживачів на молочні продукти та молоко: аналіз залежностей цін та доходів

factor of growth by an average of $5.8 \%\left(k^{\prime}=1.058\right)$, increase in real income was reduced proportionately with an increase in the number of dependent children. In 2012 the households with three or more dependent children reached level only $54.65 \%$ of the real income in comparison with the income in households without dependent children and $66.21 \%$ of the income of families with one dependent child (Table 2).

Table 2 - Development of Real Net Cash Income and Real Expenditures on Food and Nonalcoholic Beverages of Households by Number of Dependent Children in $€$ per person per year in Slovakia (authors' research)

\begin{tabular}{|c|c|c|c|c|c|c|c|c|}
\hline \multirow{2}{*}{ Year } & \multicolumn{4}{|c|}{ Real Net Cash Income } & \multicolumn{4}{c|}{$\begin{array}{c}\text { Real Expenditures on Food } \\
\text { and Non-alcoholic Beverages }\end{array}$} \\
\cline { 2 - 9 } & $\begin{array}{c}\text { Without } \\
\text { Children }\end{array}$ & $\mathbf{1}$ Child & $\mathbf{2}$ Children & $\begin{array}{c}\text { 3 and More } \\
\text { Children }\end{array}$ & No Children & 1 Child & 2 Children & $\begin{array}{c}\text { 3 and More } \\
\text { Children }\end{array}$ \\
\hline 2004 & 3298.712 & 3298.71 & 2253.86 & 1822.313 & 877.183 & 634.36 & 551.816 & 476.665 \\
\hline 2005 & 3710.947 & 3042.05 & 2486.457 & 1968.134 & 977.66 & 709.85 & 596.163 & 519.452 \\
\hline 2006 & 3889.863 & 3401.54 & 2931.654 & 2025.825 & 925.28 & 724.39 & 630.784 & 535.883 \\
\hline 2007 & 4491.967 & 3861.74 & 3194.417 & 2416.484 & 951.57 & 758.85 & 643.862 & 569.541 \\
\hline 2008 & 4876.519 & 4076.71 & 3414.672 & 2747.461 & 989.179 & 754.13 & 665.472 & 585.740 \\
\hline 2009 & 5147.610 & 4406.230 & 3472.180 & 2673.290 & 1041.00 & 779.13 & 687.380 & 602.770 \\
\hline 2010 & 5002.42 & 4314.02 & 3626.23 & 2645.26 & 1010.38 & 776.13 & 676.71 & 576.37 \\
\hline 2011 & 5138.15 & 4171.45 & 3498.07 & 2825.04 & 989.22 & 750.57 & 649.67 & 580.42 \\
\hline 2012 & 5191.11 & 4285.00 & 3537.00 & 2837.00 & 1031.20 & 785.36 & 683.90 & 613.59 \\
\hline $\begin{array}{c}\text { Growth } \\
\text { Coefficient }\end{array}$ & 1.058 & 1.033 & 1.057 & 1.057 & 1.0209 & 1.027 & 1.027 & 1.032 \\
\hline Growth Rate & 105.8 & 103.3 & 105.7 & 105.7 & 102.1 & 102.7 & 102.7 & 103.2 \\
\hline
\end{tabular}

Note: Real income and expenditures are recalculated by consumer price index, cost of living, where the previous year $=100$ ).

Rate of growth of real expenditures on food was relatively low compared to the growth of real income, which was caused by a smaller increase in inflation. As shown in Figure 4, the lowest $17.7 \%$ share of expenditures on food was noticed in families with one child, while in families with dependent children expenses slightly increased and in reporting period amounted from $19.8 \%$ to $26.5 \%$ share of the real net cash expenditures.

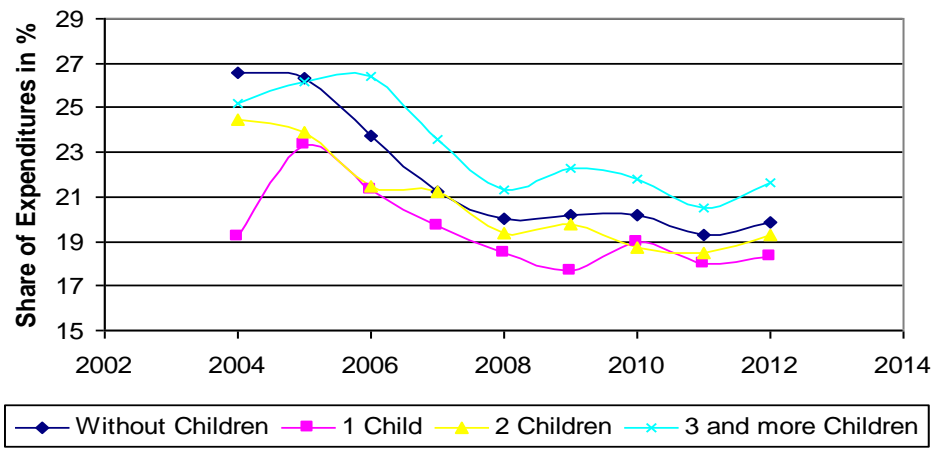

Figure 4 - Development of Real Expenditures on Food and Non-alcoholic Beverages (authors' research)

Modeling Demand for Milk in Slovakia. Consumption of skim milk in Slovak households has decreased and in 1998 fell overall by 13.3 liters and in 2012 reached the level of 50.61 liters per person in families without dependent children and the level of 45.58 liters in families with three or more dependent 
children. This downward trend in the consumption of milk in mentioned fourteen years (since 1998) has an impact on the health of the population, in particular the development and growth of young population. Experts point out that for the health and development of the organism is milk the promoting food providing the optimum ratio of many biologically active substances essential for full nutrition [12; 17; 19].

Demand (consumption) of milk in the Slovak households (Qij) relative to the consumer price $(\mathrm{Pi})$ and the average annual cash income (PR) in the reporting period 2004 to 2012 reflect the demand-linear regression functions specified in Table 3 to Table 6.

Table 3 - Estimates of Demand Function Parameters for Milk, Cheese,Yogurt and Sour Milk Products (Qi) in Households without Dependent Children in Slovakia (authors' research)

\begin{tabular}{|c|c|c|c|c|}
\hline \multirow{2}{*}{ Household without Children } & \multirow{2}{*}{$\mathbf{Q}_{\mathrm{ij}}=\mathbf{b}_{\mathbf{0}}+\mathbf{b}_{\mathbf{1}}$ price $+\mathbf{b}_{\mathbf{2}}$ income } & \multicolumn{2}{|c|}{ Elasticity } & \multirow{2}{*}{$\mathbf{R}^{2}$} \\
\cline { 3 - 6 } & $\mathrm{E}_{\mathrm{PDi}}$ & $\mathbf{E}_{\mathrm{IDi}}$ & \\
\hline Milk & $\mathrm{Q}_{\mathrm{i}, 0}=39.13+10.173 \mathrm{P}_{\mathrm{i}}+0.0019 \mathrm{PR}$ & 0.106 & 0.159 & $0.054-$ \\
\hline Cheese, Curd & $\mathrm{Q}_{\mathrm{i}, 0}=6.565-1.043 \mathrm{P}_{\mathrm{i}}+0.00167 \mathrm{PR}$ & -0.649 & 0.843 & $0.746^{* *}$ \\
\hline Other Dairy Products & $\mathrm{G}_{\mathrm{i}, 0}=17.92-6.938 \mathrm{P}_{\mathrm{i}}+0.0013 \mathrm{PR}$ & -1.346 & 0.529 & $0.654^{* *}$ \\
\hline Yogurts & $\mathrm{Q}_{\mathrm{i}, 0}=10.37-2.423 \mathrm{P}_{\mathrm{i}}+0.0011 \mathrm{PR}$ & -0.615 & 0.536 & $0.795^{* *}$ \\
\hline
\end{tabular}

Note: - model statistically significant at the $10 \%$ significance level

${ }^{*}$ model statistically significant at the $5 \%$ significance level $(a<0.05)$

In households without dependent children the demand function coefficients characterizing the impact of milk prices and the impact of the income attributable to one member is statistically inconclusive. Consumer demand did not refer the theoretical principles of demand and increasing own milk prices did not result in decreasing of demand. Consumption patterns of other milk products in the segment of households have statistical significance and consumption was carried out according to the law of the market. Demand for milk, cheese and yoghurt was income and price inelastic that shows the same results in four price inelasticity milk categories- namely premium milk, whole milk, low - fat milk according to a study by [22, p. 1485]. Only demand for other dairy products was price elastic (EPDi $=-1.346)$, which was reflected in the fact that at an average consumption of $11.51 \mathrm{~kg}$ of other dairy products per person per year and the average retail price of $€ 2.232$ per $\mathrm{kg}$ and cash income $€ 4688.2$ per person per year, the price increase by one percent declined decreasing of its demand by $-1.346 \%$.

Table 4 - Estimates of Demand Function Parameters for Milk, Cheese,Yogurt and Sour Milk Products (Qi) in Households with One Dependent Child (authors' research)

\begin{tabular}{|c|c|c|c|c|}
\hline \multirow{2}{*}{ Household with One Child } & \multirow{2}{*}{$\mathbf{Q}_{\mathrm{ij}}=\mathbf{b}_{\mathbf{0}}+\mathbf{b}_{\mathbf{1}}$ price $+\mathbf{b}_{\mathbf{2}}$ income } & \multicolumn{2}{|c|}{ Elasticity } & \multirow{2}{*}{$\mathbf{R}^{\mathbf{2}}$} \\
\cline { 2 - 5 } & $\mathbf{E}_{\mathrm{PDi}}$ & $\mathbf{E}_{\mathrm{IDi}}$ & \\
\hline Milk & $\mathrm{Q}_{\mathrm{i}, 1}=48.79-0.163 \mathrm{P}_{\mathrm{i}}-0.0007 \mathrm{PR}$ & -0.002 & -0.060 & $0.015-$ \\
\hline Cheese, Curd & $\mathrm{Q}_{\mathrm{i}, 1}=4.68-0.349 \mathrm{P}_{\mathrm{i}}+0.0010 \mathrm{PR}$ & -0.282 & 0.568 & $0.800^{* *}$ \\
\hline Other Dairy Products & $\mathrm{Q}_{\mathrm{i}, 1}=14.78-6.432 \mathrm{P}_{\mathrm{i}}+0.00153 \mathrm{PR}$ & -1.925 & 0.769 & $0.497^{*}$ \\
\hline Yogurts & $\mathrm{Q}_{\mathrm{i}, 1}=8.264-1.115 \mathrm{P}_{\mathrm{i}}+0.00079 \mathrm{PR}$ & -0.328 & 0.366 & $0.446^{*}$ \\
\hline
\end{tabular}

Note: - model statistically significant at the $10 \%$ significance leve

${ }^{*}$ model statistically significant at the $5 \%$ significance level $(a<0.05)$

Consumer demand for milk and dairy products in households with one dependent child was conducted according to the law of demand. Presented regression models show statistical evidence supporting the $5 \%$ significance level alongside the demand for milk that is not statistically significant. Income elasticity of demand for milk has a negative value $\left(E_{\text {ldi }}=-0.060\right)$ and milk appears in the household segment as inferior (inferior good) and income increase by one percentage point would reduce demand for milk by $0.060 \%$. On the other hand, demand for other dairy products was price-elastic (flexible). 
With an average consumption of $17.94 \mathrm{~kg}$ of other dairy products per year and the average retail price of $€ 2.38$ per liter and cash income $€ 3956.26$ per person per year, the price increasing by one percent decreased its demand by $-1.925 \%$ and significantly reduced consumption. Demand for milk, cheese and yogurt was price-inelastic and was conducted according to the law of supply and demand (Table 4).

Table 5 - Estimates of Demand Function Parameters for Milk, Cheese,Yogurt and Sour Milk Products (Qii) in Households with Two Dependent Children in Slovakia (authors' research)

\begin{tabular}{|c|c|c|c|c|}
\hline \multirow{2}{*}{ Household with Two Children } & \multirow{2}{*}{$Q_{i j}=b_{0}+b_{1}$ price $+b_{2}$ income } & \multicolumn{2}{|c|}{ Elasticity } & \multirow{2}{*}{$\mathbf{R}^{2}$} \\
\hline & & $\mathrm{E}_{\mathrm{PDi}}$ & $E_{I D i}$ & \\
\hline Milk & $Q_{i, 2}=11.14+9.187 P_{i}-0.0087 P R$ & 0.115 & -0.656 & $0.597^{*}$ \\
\hline Cheese, Curd & $Q_{i, 2}=5.23-0.454 P_{i}+0.00095 P R$ & -0.421 & 0.555 & $0.897^{* \star}$ \\
\hline Other Dairy Products & $Q_{\mathrm{i}, 2}=7.15-2.073 \mathrm{P}_{\mathrm{i}}+0.0015 \mathrm{PR}$ & -0.691 & 0.701 & $0.821^{* *}$ \\
\hline Yogurts & $Q_{\mathrm{i}, 2}=11.67-2.838 \mathrm{P}_{\mathrm{i}}+0.0010 \mathrm{PR}$ & -0.856 & 0.429 & $0.827^{* \star}$ \\
\hline
\end{tabular}

Based on estimated regression models of demand for dairy products can be characterized the demand for milk in households with two dependent children as the inferior (inferior good), where increasing of income by one percent resulted in decreasing of demand for milk by $-0.656 \%$ and growth in milk prices did not cause a decrease in consumption of milk $\left(E_{P_{d i}}=0.115\right)$ and was contrary to the laws of the market. Households with two children response more sensitive to the rise in prices of yoghurts and coefficient of price elasticity $\left(E_{P d i}=-0.856\right)$ is approaching the limit of elasticity. One percent increase in the price of yogurt resulted in a reduction in demand for yoghurts by $-0.856 \%$ for other dairy productsabout $0.691 \%$ and cheese by $-0.421 \%$ (Table 5 ).

Table 6 - Estimates of Demand Function Parameters for Milk, Cheese,Yogurt and Sour Milk Products (Qii) in Households with Three and More Dependent Children in Slovakia (authors' research)

\begin{tabular}{|c|c|c|c|c|}
\hline \multirow{2}{*}{$\begin{array}{l}\text { Household with Three and More } \\
\text { Children }\end{array}$} & \multirow{2}{*}{$Q_{i j}=b_{0}+b_{1}$ price $+b_{2}$ income } & \multicolumn{2}{|c|}{ Elasticity } & \multirow{2}{*}{$\mathbf{R}^{2}$} \\
\hline & & $\mathrm{E}_{\mathrm{PDi}}$ & $E_{I D i}$ & \\
\hline Milk & $Q_{i, 3}=23.54+19.526 P_{i}+0.0041 P R$ & 0.249 & 0.004 & $0.207^{-}$ \\
\hline Cheese, Curd & $Q_{i, 3}=5.58-1.009 P_{i}+0.0018 P R$ & -1.148 & 0.946 & $0.845^{\star \star}$ \\
\hline Other Dairy Products & $Q_{i, 3}=6.95-3.075 P_{i}+0.0024 P R$ & -1.163 & 0.993 & $0.876^{* *}$ \\
\hline Yogurts & $Q_{i, 3}=-5.76-3.613 P_{i}+0.0013 P R$ & -1.245 & 0.469 & $0.797^{\star *}$ \\
\hline
\end{tabular}

In the households with three or more dependent children the demand function coefficients characterizing the impact of the prices of dairy products and impact of income in households with three or more dependent children have significance at $a=0.01 \%$. The demand for milk is statistically inconclusive and was conducted according to the law of supply and demand. Increasing the milk prices by one percent increased the consumption demand by $0.249 \%$. According the given income was price-elastic demand in the consumption of cheese, other dairy products and yoghurts, for the purchase of which one percent increase in consumer prices resulted in a decline in demand by more than one percent (EPDi, $=-1.148$ to 1.245). The families with more members have not only the lowest total consumption expenditures but also the lowest real expenditures for food and non-alcoholic beverages. In 2012, real expenditures on food and non-alcoholic beverages were amounted to an average of $€ 613.59$ per person, while in the families without children the real food expenses were at $€ 1,031.2$ and thus higher by $1.68 \%$ (Table 6 ). 
Modeling Substitution Relations of Demand for Milk in Slovakia.Milk nutrition accompanies man from birth throughout whole life. It is also the raw material for manufacturing the other food products, allowing the market to offer a wide and varied range of alternative products. Physico-chemical characteristics of some components of milk allow producing a wide variety of new products [23, p. 75]. Current surveys shows that the price, taste, brand and product quality influence the consumption and demand for milk and dairy products the most [24, p. 15; 27]. Decreasing consumption of milk implies very low consumer awareness about its irreplaceable role in healthy human nutrition. Generational decline in the consumption of milk is also reflected in the US [6]. To present the milk as one of the most important sources of nutrition and good health is also awareness in families and especially among schoolchildren. Intake of up to three servings of dairy products per day appears to be safe and may confer a favorable benefit with regard to bone health [24, p. 14].

Substitution and complementary relations in the monitoring of milk consumption in monitored households $\mathrm{Gij}$ relative to consumer prices $\mathrm{Pi}$ and cash income quantify regression coefficients in Table 7.

Table 7 - Modeling Substitution Relations of Demand for Milk ( $\left.Q_{i}\right)$ in Slovakia (authors' research)

\begin{tabular}{|c|c|c|c|c|c|c|}
\hline \multirow{2}{*}{ Household } & \multirow{2}{*}{$Q_{i, j}=b_{0}+b_{1} P_{1}+b_{2} P_{2}+b_{3} P_{3}+b_{4} P_{4}+b_{5} P_{5}$} & \multicolumn{5}{|c|}{ Elasticities } \\
\hline & & $\mathrm{Eq}_{\mathrm{i}}, \mathbf{P}_{1}$ & $\mathrm{Eq}_{\mathrm{i}}, \mathrm{P}_{2}$ & $\mathrm{Eq}_{\mathrm{i}}, \mathrm{P}_{3}$ & $\mathrm{P}_{4} \mathrm{Eq}_{\mathrm{i}}$ & $E q_{i}, P_{5}$ \\
\hline $\begin{array}{l}\text { Without } \\
\text { Children }\end{array}$ & $\begin{array}{c}\mathrm{Q}_{\mathrm{i}, 0}=159.02+144.3 \mathrm{P}_{1}+26.67 \mathrm{P}_{2}-11.98 \mathrm{P}_{3}- \\
121.65 \mathrm{P}_{4}+0.0244 \mathrm{P}_{5}\end{array}$ & 1.51 & 1.062 & -1.14 & -2.27 & 2.041 \\
\hline One Child & $\begin{array}{c}\mathrm{Q}_{\mathrm{i}, 1}=57.99+50.152 \mathrm{P}_{1}-30.653 \mathrm{P}_{2}-8.56 \mathrm{P}_{3}+ \\
24.61 \mathrm{P}_{4}+0.0045 \mathrm{P}_{5}\end{array}$ & 0.636 & -1.59 & -1.052 & 1.357 & 0.388 \\
\hline Two Children & $\begin{array}{c}Q_{i, 21}=41.23+110.79 P_{1}-5.24 P_{2}-21.21 P_{3}- \\
14.79 P_{4}+0.0115 P_{5}\end{array}$ & 1.31 & -0.267 & -2.468 & -0.739 & 0.819 \\
\hline $\begin{array}{l}\text { Three and } \\
\text { More Children }\end{array}$ & $\begin{array}{c}\mathrm{Q}_{\mathrm{i}, 3}=82.26+90.46 \mathrm{P}_{1}+46.5 \mathrm{P}_{2}-17.05 \mathrm{P}_{3}- \\
68.29 \mathrm{P}_{4}+0.024 \mathrm{P}_{5}\end{array}$ & 1.150 & 2.373 & -0.249 & -3.644 & 1.342 \\
\hline
\end{tabular}

Note: $P_{1}$ price of milk, $P_{2}$ price of other dairy products, $P_{3}$ price of cheese, $P_{4}$ price of yogurt, $P_{5}$ Net Cash Income.

Direct (own) price elasticity of demand for milk (Gii) is expressed by parameter $b_{1}$. In families without dependent children has a value $1.51\left(E_{\mathrm{qi}, 1}=1.51\right)$ and points out that the increase in the price of milk by one per cent with an average consumption of 56.04 liters and the average annual income of $€ 4,688.2$ resulted in the increase in demand for milk by $1.51 \%$ and demand did not take place according to market laws. Identical consumer behavior in terms of consumer prices for milk has been noticed also in the other households. The demand for milk under indirect (crisis) price elasticity was carried out elastically and was substituted by other dairy products in the households without children $\left(\mathrm{Eq}_{1}, \mathrm{P}_{2}=1.062\right)$ and in the households with three or more children $\left(\mathrm{Eq}_{1}, \mathrm{P}_{2}=2.373\right)$, while the demand for cheese fulfill complementary (additional) function of nutrition $\left(\mathrm{Eq}_{\mathrm{i}}, \mathrm{P}_{3}=-2.468\right.$ to -0.249$)$ and the rise in the price of one product resulted in a reduction in consumption of other product. Yoghurt consumption acts as a complementary food excluding the households with one child, where yogurt has a substitute function $\left(\mathrm{Eq}_{\mathrm{i}} \mathrm{P}_{4}=1.357\right)$ and a rise in the price of one product increases demand for other product.

Income elasticity of demand characterized by regression parameter $b_{5}$ measures the flexibility elasticity of demand for drinking milk and milk products due to changes in cash income. Positive values of the coefficient of elasticity $b_{5}$ indicate that milk is a normal good. In households without children and with three or more children increase of cash income by $1 \%$ resulted in an increase in demand for milk by more than $1 \%\left(E q_{i}, P_{5}=2.041\right.$ to 1.342$)$ so expenses grew faster than income.

Conclusion and directions of further researches. Based on the results presented in the paper it is to be noted that in the reporting period from 2004 to 2012 was observed upward trend in demand for other dairy products, curd, cheese and yoghurts. This positive trend in consumption of dairy products with greater added value was accompanied by the annual descent of demand for milk. Overall, based on the average 
growth rate $\mathrm{k}^{\prime}$ can be concluded that there was increase in consumption of dairy products by an average annual rate of $0.4 \%\left(k^{\prime}=1.004\right)$ as well as the curd and cheese consumption by an average annual rate of $2.1 \%\left(k^{\prime}=1.021\right)$.

In the households without dependent children the consumer demand for milk did not take place according to the law of supply and demand. The demand for milk, cheese and yoghurt was income and price inelastic while the demand for other dairy products was price-elastic $\left(E_{P D i}=-1.346\right)$.

Consumer demand for dairy products in the households with one dependent child was conducted according to the law of demand. Income elasticity of demand for milk had a negative value $\left(E_{\text {ldi }}=-0.060\right)$ and milk appears in this household segment as inferior (inferior good) when increasing of income by one percentage point reduced demand for milk by $0.060 \%$. On the other hand, demand for other dairy products was price-elastic (flexible). The price increase by one percent caused decline in demand for other dairy products by $-1.925 \%$ and significantly reduced consumption. Demand for cheese and yogurt was priced inelastic and was conducted according to the law of supply and demand.

Demand for milk in the households with two dependent children was as with the inferior (inferior good), when increasing income by one percent resulted in decreasing demand for milk by $-0.656 \%$ and growth the milk prices did not cause a decrease in milk consumption $\left(E_{p d i}=0.115\right)$ and contrary to the laws of the market. Households with two dependent children reacted quite sensitive to increasing prices of yoghurts and coefficient of price elasticity $\left(E_{P d i}=-0.856\right)$ was approaching the limit of elasticity. One percent increase in prices of yogurt resulted in a reduction in demand for yoghurts by $-0.856 \%$, sour milk products by $-0.691 \%$ and cheese by $-0.421 \%$.

In the households with three or more dependent children, the demand for milk was conducted according to the law of supply and demand. One percent increase in milk prices was leading to an increase in consumption demand by $0.249 \%$. In the consumption of cheese, yoghurt and sour milk products, increasing consumer prices resulted in declining of demand by more than one percent (EpDi = 1.148 to -1.245 ), demand was elastic and developing according to the law of demand.

Demand for milk based on indirect (cross) price elasticity was elastic and substituted by other dairy products in the households without children (Eqi, P2 $=1.062$ ) and in the households with three or more dependent children (Eqi, P2 $=2.373$ ), while the demand for cheese was fulfilling complementary (additional) function of nutrition (Eqi, P3 $=-2.468$ to -0.249 ). Yoghurt consumption in the households without dependent children and in the households with three or more dependent children was representing a complementary food. In the households with one dependent child, yogurt consumption substituted the consumption of milk $\left(\mathrm{Eq}_{\mathrm{i}} \mathrm{P}_{4}=1.357\right)$ and increasing of the price of one product caused increasing demand for other product.

1. Berčík, J., Paluchová, \& J. Horská, E. (2016). Neuroeconomics: An Innovative View on Consumer's Decision Process Journal of Business Management \& Economics, 4 (8), 22-28.

2. Bielik, P., Smutka, L., \& Horská, E. (2013). Visegrad countries'agricultural production. In: BIELIK, P. Sustainable development and agribusiness (pp. 35-45). Warszawa : Wieś Jutra.

3. Bowen, J., Noakes, M., Trenerry,C., \& Clifton, P. (2006). Energy intake, ghrelin and cholecystokinin after different carbohydrate and protein preloads in overweight men. J Clin Endocrinol Metab, 91, 1477-1483.

4. Bujko, J., Kocman, R., Žitný, J., Trakovická, A., \& Hrnčár, C. (2011). Analyse of traits of milk production in dairy cows. Potravinarstvo, 1 (1), 5-9.

5. De Smet, S. et al. (2015). The influence of dairy consumption and physical activity on ultrasound bone measurements in Flemish children. Journal of Bone and Mineral Metabolism, 33 (2), 192-200.

6. Diepvens, K., Haberer, D., Westerter, P., \& Plantenga, M. (2008). Different proteins and biopeptides differently affect satiety and anorexigenic/orexigenic hormones in healthy humans. Int J Obes (Lond), 32, 510-518.

7. Dougkas, A., Reynolds, C.K., Givens, I.D., Elwood, P.C., \& Minihane, A.M. (2011). Associations between dairy consumption and body weight: a review of the evidence and underlying mechanisms. Nutr Res Rev 1-24.

8. Fox, P.F., Uniacke-Lowe, T., Mcsweeney, P. L. H., \& O'Mahony, J.A. (2015). Biologically Active Compounds in Milk. 
Dairy Chemistry and Biochemistry, 415-497.

9. Habánová, M., Lorková, M \& Kopčeková, J. (2010). The consumption of acydophylus drinks and Yogurts in selekted population of pupils in years 2004 and 2008. Potravinárstvo, vol. 3, no. 3, p. 19-23.

10. Hayden S., Diansheng D., \& Andreas C. (2012). Is Gerenational Change Contributing to the Deckline in Fluid Milk Consumption? Journal of Agricultural and Resorsce Economics, 37 (3), 435-454.

11. Elmandfa, I., et al. (2009). Ôsterreichischer Ernährungsbericht. Auflage : Wien.

12. Holota T., Hrubec, J., Kotus, M., Holienčinová M., \& Čapošová E. (2016). The management of quality costs analysis model. Serbian journal of management, 11 (1), 119-127.

13. Jůzl, M. (2015). Mléko a mléčné výrobky, význam mléka a mýty o jeho konzumaci [Milk and dairy products, meaning of milk and myths about its consumption]. Výživa a potravin - Nutrition and food, 3 (3), 43-45 [in Czech].

14. Košičiarová ${ }_{1}$ I. (2012). Cenová politika obchodných retáazcov predávajúcich biopotraviny [Pricing policy of chain stores selling organic food]. Brno: Mendel University in Brno [in Czech].

15. Kubicová, L'., \& Kádeková, Z. (2011). Comparison of the income development and the food demand elasticities of the private households in Slovakia. Agricultural economics, 57 (8), 404-411.

16. Lovayová, V., Dudriková, E., Nemcová, R., \& Rimárová, K. (2010): Influence of the ripening onto the growth of selekted probiotic cultures in low-cooked cheese. Potravinárstvo, 3 (3), 40-45.

17. Lengyelová,L., Kozelová, D., Trstenovičová, L'., \& Pinterová, S. (2010). Comparison of occurence lactic acid bakrteria in chosen yogurts. Potravinárstvo, 4 (4), 38-43.

18. Mehrabani, S. et al. (2015). Effects of low-fat milk consumption at breakfast on satiety and short-term energy intake in 10- to 12-year-old obese boys. European Journal of Nutrition, 1-8.

19. Nagyová, L'. et al. (2014 a). Výskum trhu. [Market Research]. Nitra : SUA [in Slovak].

20. Nagyová, L'. et al. (2014 b). Marketing. Nitra : SUA [in Slovak].

21. Nagyová, L'., Holienčinová, M., Košičiarová, I., \& Holota, T. (2016). Corporate social responsibility in food manufacturing companies - environmental dimensions. Acta Universitatis Agriculturae et Silviculturae Mendelianae Brunensis, 64 (3), $1037-1043$.

22. Nagyová, L'., Košičiarová, I., \& Holienčinová, M. (2016). Sustainable consumption of food: a case study of Slovak consumers. Economic science for rural development. Jelgava: Latvijas Lauksaimnieci bas universita te. Ekonomikas fakulta te.

23. Natsuki, S., Syusuke, T., Katsutoshi, Y., \& Tomomichi, S. (2014). Evaluation of price elasticity and brand loyalty in milk products. Procedia Computer Science, 35, 1482-1487.

24. Niclas, T.A., O'Neil, C.E., \& Fulkoni, V.I. (2009). The role of dairy in meeting the recommendations for shortfall nutriens diet. J. Am. Coll. Nutr., 28, $73-81$.

25. Rozenberg, S. et al. (2016). Effects of Dairy Products Consumption on Health: Benefits and Beliefs-a Commentary from the Belgian Bone Club and the European Society for Clinical and Economic Aspects of Osteoporosis, Osteoarthritis and Musculoskeletal Diseases. Calcified Tissue International, 98 (1), 1-17.

26. Šugrová, M., Šedík, P., \& Svetlíková, V. (2016). Brand influence of young generations's decisions in purchasing yogurts in the Slovak Republic. Future scientists for sustainable development. Gödöllö: Szent István University, 482--495.

27. Šnirc, J., Golian, J. et al. (2015). Mlieko, mliečné výrobky. 1.diel. Štruktúra, bioaktívne zložky a spracovanie mlieka [Milk, dairy products. 1.edition. Structure, bioactive ingredients and milk processing]. Nitra : SUA [in Slovak].

28. Štatistický úrad SR. (2015). Prijmy, výdavky a spotreba súkromných domácností SR. [Revenue, expenditure and consumption of private households in the SR.]. Bratislava. [in Slovak].

29. Valík, L'. (2006). Prospešnost' konzumácie mlieka [Utility consumption of milk]. Výživa a zdravie -Nutrition and health, 50 (3-4), 15 [in Slovak].

Л. Кубіцова, PhD., доцент кафедри маркетингу та торгівлі, факультет економіки та менеджменту, Словацький аграрний університет (м. Нітра, Словакія);

3. Кадекова, PhD., кафедра маркетингу та торгівлі, фракультет економіки та менеджменту, Словацький аграрний університет (м. Нітра, Словакія);

Л. Нагіова, PhD., професор кафедри маркетингу та торгівлі, факультет економіки та менеджменту, Словацький аграрний університет (м. Нітра, Словакія);

П. Ровний, PhD., доцент кафедри маркетингу та торгівлі, факультет економіки та менеджменту, Словацький аграрний університет (м. Нітра, Словакія);

Попит словацьких споживачів на молочні продукти та молоко: аналіз залежностей цін та доходів

Метою статті був кількісний аналіз детермінантів попиту та рівня споживання молока та молочних продуктів залежно від споживчих цін на молочні продукти та наявного доходу стосовно сегменту домогосподарств з дітьми, які знаходяться на утриманні. Сучасні економічні умови у Словаччині сприяють дифреренціації поведінки домогосподарств на споживчому ринку. Це помітно в основному в сім'ях з декількома дітьми, які знаходяться на утриманні. у 2012 році реальний грошовий дохід домогосподарств з трьома або більше такими дітьми становив лише $54.65 \%$ реального доходу порівняно з доходами сімей без таких дітей та 66.21\% доходу сімей з однією такою дитиною. У словацьких домогосподарствах споживання молока в иілому знижується. 31998 року воно скоротилося на 13.3 літра та у 
2012 році досяело рівня 50.61 літра на особу в сім'ях без дітей, які перебувають на утриманні, а також 45.58 літра у сім'ях з трьома або більше такими дітьми. Попит на молоко не розвивався відповідно до теоретичних припущень. Збільшення ціни не призвело до зниження попиту за винятком сімей з однією дитиною, яка знаходиться на утриманні. Базуючись на непрямій (перехресній) ціновій еластичності, слід зазначити, що попит був еластичним і відрізнявся $ө$ сім'ях без дітей $\left(E q_{i,} P_{2}=1.062\right)$ та в домогосподарствах з трьома або більше дітьми, які перебувають на утриманні $\left(E q_{i}, P_{2}=2.373\right)$, по інших молочних продуктах. Споживчий попит на сир та йогурт виконував доповнюючу (додаткову) функцію в харчуванні (Eq, $P_{3}=-2.468$ to -0.249). Значна взаємодоповнюваність вказала на попит щодо йогурту в сім'ях з трьома або більще дітьми, які перебувають на утриманні ( $\left.E q_{i}, p_{4}=-3.644\right)$, та сім'ях без таких дітей $\left(E q_{i}, p_{4}=-2.27\right)$,

Ключові слова: дохід, споживання, еластичність цін та доходів, замінюваність, взаємодоповнюваність.

Л. Кубицова, PhD., доцент кафедры маркетинга и торговли, факультет экономики и менеджмента, Словацкий аграрный университет (г. Нитра, Словакия);

3. Кадекова, PhD., кафедра маркетинга и торговли, факультет экономики и менеджмента, Словацкий аграрный университет (г. Нитра, Словакия);

Л. Нагиова, PhD., профессор кафедры маркетинга и торговли, факультет экономики и менеджмента, Словацкий аграрный университет (г. Нитра, Словакия);

П. Ровный, $\mathrm{PhD}$., профессор кафедры маркетинга и торговли, факультет экономики и менеджмента, Словацкий аграрный университет (г. Нитра, Словакия)

Спрос словацких потребителей на молочные продукты и молоко: анализ зависимостей цен и доходов

Целью этой статьи являлся количественный анализ детерминант спроса и уровня потребления молока и молочных продуктов в зависимости от потребительских иен на молочные продукты и имеющегося дохода по потребительскому сегменту домохозяйств с детьми, находящимися на содержании. Современные экономические условия в Словакии способствуют диффференциации поведения домохозяйств на потребительском рынке. Это заметно в основном в семьях с несколькими детьми, которые находятся на содержании. В 2012 году реальный денежный доход домохозяйств с тремя или более такими детьми составил всего $54.65 \%$ реального дохода по сравнению с доходами семей без таких детей и $66.21 \%$ дохода семей с одним таким ребенком. В словацких домохозяйствах потребление молока в целом снижается. С 1998 года оно сократилось на 13.3 литра и в 2012 году достиело уровня 50.61 литра на человека в семьях без детей, находящимися на содержании, а также 45.58 литра в семьях с тремя или более такими детьми. Спрос на молоко не развивался в соответствии с теоретическими предположениями. Увеличение цены не привело к снижению спроса за исключением семей с одним ребенком, находящимся на содержании. Основываясь на непрямой (перекрестной) ценовой эластичности, следует отметить, что спрос был эластичным и отличался в семьях без детей $\left(E q_{i}, P_{2}=1.062\right)$ и в домохозяйствах с тремя или более детьми, находящимися на содержании $\left(E q_{i}, P_{2}=2.373\right)$, по другим молочным продуктам. Потребительский спрос на сыр и йогурт выполнял дополняющую (дополнительную) фуункцию в питании ( $E q_{i,}, P_{3}=-2.468$ to -0.249$)$. Значительная взаимодополняемость указала на спрос в йогурте в семьях с тремя или более детьми, находящимися на содержании $\left(E q_{i}, p_{4}=-3.644\right)$, и семьях без таких детей $\left(E q_{i}, p_{4}=-2.27\right)$

Ключевые слова: доход, потребление, эластичность цен и доходов, заменяемость, взаимодополняемость.

Отримано 29.03.2017 p. 